University of Michigan Law School

University of Michigan Law School Scholarship Repository

Articles

Faculty Scholarship

1922

\title{
Mutuality in Specific Performance
}

Edgar N. Durfee

University of Michigan Law School

Available at: https://repository.law.umich.edu/articles/994

Follow this and additional works at: https://repository.law.umich.edu/articles

Part of the Common Law Commons, Contracts Commons, and the Legal Remedies Commons

\section{Recommended Citation}

Durfee, Edgar N. "Mutuality in Specific Performance." Mich. L. Rev. 20 (1922): 289-314.

This Article is brought to you for free and open access by the Faculty Scholarship at University of Michigan Law School Scholarship Repository. It has been accepted for inclusion in Articles by an authorized administrator of University of Michigan Law School Scholarship Repository. For more information, please contact mlaw.repository@umich.edu. 


\section{MUTUALITY IN SPECIFIC PERFORMANCE}

\section{The Older Conceptition of Mutuality-ËQuality or IDENTITY OF REMIEDY}

PRIOR to the present century, the subject of mutuality in specific performance was an unsolved puzzle. The decisions of the courts were in the main wise, but the attempts both of courts and text writers to formulate a statement of the principle governing these decisions were far from happy. After two centuries of litigation and discussion, the current formula was that the remedy must be mutual, must be equally available to both parties. The worst fault of this formula was its plausibility. Equality is equity, and perfect equality between the parties to a contract is not attained unless remedies are equally available to both. ${ }^{1}$ The plausibility of the doctrine served to keep it alive, even to this day.

It was of the essence of this doctrine that the decision of a cause should be governed, not solely by the situation presented to the court, but as well by the situation which would have been presented in a certain hypothetical case which might have arisen if the now complainant had breached the contract and the now defendant had sued for specific performance. The doctrine was understood to have two aspects, one affirmative, one negative. By the former, complainant, although he had an adequate remedy at law, should be given relief if, in the hypothetical converse case, the other party would have been entitled to relief (provided that there was no affirmative objection to the relief sought in the case before the court, such as impossibility of compelling performance). By the negative doctrine, complainant, although entitled to relief in every other respect, should be denied relief if, in the hypothetical converse case, the remedy could not or would not (even on the affirmative doctrine of mutuality) be given to the other party. Stated in this form, the doctrine seems unbelievably academic, yet this is but a

1 Eloquent is the expression of the principle by Commissioner Brown, in McCall v. Atchley, 256 Mo. 39, 54: "It stands upon the foundation of all equitable jurisprudence, which distributes justice with an impartial hand and withholds its extraordinary remedies from those who have not submitted themselves freely to its jurisdiction." 
paraphrase in more precise terms of dogmas formulated a hundred times by hard-headed judges. ${ }^{2}$

It is obvious that there is a vast difference between the affirmative and negative doctrines. No hardship is caused by the affirmative doctrine. Indeed, one must consider its operation beneficent if hè agrees with Justice Story that on principles of natural justice equity should grant specific performance of all contracts at the election of the injured party, instead of leaving to the other his common law election to perform or pay damages. ${ }^{3}$ Without going the length of Story's position, it may be said that, since there is no substantial equity to oppose relief, the equity of equality is suffi-

2 This statement of the doctrine contains only two features which are not commonplace in the books-(I) the stamping of the converse case as a hypothetical, which it certainly is, and (2) the inclusion of the bracketed clauses, which must always have been implied, since without them the two doctrines, affirmative and negative, could not stand together.

Justice Fry crystalized the negative doctrine in the well-known passage: "A contract to be specifically enforced by the court must, as a general rule, be mutual,- that is to say, such that it might, at the time it was entered into, have been enforced by either of the parties against the other of them. Whenever, therefore, whether from personal incapacity to contract, or the nature of the contract, or any other cause, the contract is incapable of being enforced against one party, that party is equally incapable of enforcing it against the other, though its execution in the latter way might in itself be free from the difficulty attending its execution in the former." SPFCIFIC Performance ( 1858 ), \$286. There was very little in the decision of that time to support this broad formula, and very little in the English cases since. See 42 Am. I. REG. (n. s.) 624. But Fry's formula was adopted almost verbatim by $J$. N. Pomeroy in his Specific Performance (I879), \$I62 ff., and endorsed to the extent of adverse criticism of one of the settled exceptions. Waterman also embraced the heresy: Specific PERFormance (I88I), $\$ I 96 \mathrm{ff}$. Through these channels, or directly, Fry's formula found its way into the American cases and became commonplace by the end of the last century.

The American courts and writers have seriously confused the subject by linking with this doctrine of mutuality or equality of remedy the statement that the contract must be mutual in its obligation. At best, this is but an inept way of stating that defendant's promise must be supported by a consideration. Taken literally, it is untrue and seriously misleading. This particular phase of the subject is best disposed of in the scholarly article by Dean Harlan F. Stone in I6 Cor. L. REv. 443. See also 36 Cyc. 622.

3 STORY, EQ. JUR. (Ed. I3), \$7r7a. Approved and declared to be the goal toward which equity is progressing, in Curtice Bros. Co. v. Catts, 72 N. J. Eq. 83I, and Phillips v. Berger, 2 Barb. 608 . 
cient basis for giving relief. The doctrine has been rejected by some courts, and there is reason for doubting its universality even in those jurisdictions where it has been accepted, but it cannot be denied that it is an active principle of equity. ${ }^{4}$

On the other hand, the negative doctrine, if ruthlessly applied, would work constant hardship. That one who suffers from breach of contract and has no adequate remedy at law should be turned away from a court of equity because of an "equity" as attenuated as the equity of equality, set up by the contract breaker, is intolerable. The fallacy of such an application of the principle of equality lies in over-emphasis of an essentially sound principle and failure to balance against it the conflicting equities, a fallacy against which equity must stand constant guard. The courts, without seeing the problem broadly enough to recognize the inherent weakness of the doctrine of equality of remedy, ${ }^{5}$ could not but feel the intolerable harshness of its negative application and almost uniformly refused to so apply it. The result was that the negative doctrine was embroidered with exceptions. Justice Fry stated four exceptions, ${ }^{\circ}$ Dean Ames eight, ${ }^{7}$ and Clark ten. ${ }^{8}$ The exceptions literally ate up the rule. Yet the rule continued to receive lip service, and cases arriving at absurd results by a conscientious application of the rule are sufficiently numerous to demonstrate the danger of false doctrine. Judicial instinct will usually correct the errors of judicial reasoning, but not invariably.

4 The affirmative doctrine is fully discussed in $4 \mathrm{I}$ AM. L. REG. (n. s.) 65 (W. D. Lewis), and I IA. L. BUL. 53 (H. C. Horack). See also 3 CoL. I. REv. II, I2.

5 But in Zelleken v. Lynch, 80 Kan. 746, Justice Burch put a rude finger on the sore spot, saying: "If equity has no remedy to prevent the defendants from confiscating to their own use this increment in the value of their land, from compelling the plaintiffs to sacrifice their expenditure of time and labor and money, and from cutting off the plaintiffs from the just profits of the venture, it is a very anemic system and needs to be recruited with a stock of robust, virile principles which will enable it to cope with fraud. $* * *$ Plaintiffs' claims appeal to conscience and are unopposed by any countervailing equity on the defendants' side."

- SpectFic Performance, \$2go, ff.

${ }^{7} 3$ COL. I. REV. I.

8 EQuiry, $\$ 175, f f$. In all, there are at least twelve exceptions to the rule as stated above. Clark omits reference to two of the exceptions noted by Fry. 
The first years of the present century saw a simultaneous attack, from apparently independent quarters, upon this doctrine of equality or identity of remedy." Ashburner, in his "Principles of Equity" (I902), said: "It does not appear to form the ratio decidendi of any line of cases."10 Mr. William Draper Lewis, in a series of scholarly articles in the AMERICAN IAAW REGISTER (I9OI-I903), ,1 traced the history of the doctrine, exposed the fallacy that underlay it, and showed that (barring a handful of decisions which are clearly opposed to the current of authority) the cases in which relief has been refused on the ground of want of mutuality involved on the facts a principle much more substantial than equality of remedy. Much the same results were achieved in brief compass by the late Dean Ames in a masterly article in the CoLUMBIA LAw REVIEW (1903). ${ }^{12}$ These scholarly lawyers demonstrated that the negative doctrine of equality of remedy never was the living law, the law in action. And though the courts continue all too frequently to repeat the old shibboleth, ${ }^{13}$ there is a growing tendency to accept the views of Ames and Lewis and to pronounce a sounder doctrine of mutuality. ${ }^{14}$

9 The doctrine has gone by the name of "mutuality" or "mutuality of remedy," but for the sake of avoiding confusion as between this doctrine and that of "mutuality of performance" the writer will in this paper consistently refer to the former as "equality of remedy," a phrase suggestive of the rationale of the doctrine, or "identity of remedy," a phrase more accurately descriptive of the doctrine than either of the others. Perhaps the term "convertibility of remedy" would be the most accurate of all.

${ }^{10}$ EQUITY, \$557. It was distinctly easier to say this of the English than of the American cases, for the dogma of equality had received much more recognition on this side of the Atlantic than on the other. See 42 AM. L. REG. (n. s.) 624 . 59 .

1140 AMr. L. REG. (n. s.) 270, 383, 447, 507; 4I ib. 25I, 329, 523; 42 ib.

123 CoL. L. REV. I.

13 Roller v. Weigle, 26I Fed. 250; Antero, etc., Co. v. Lowe (Ca1.), 194 Pac. 945; Lee v. Lloyd, I8I N. Y. Supp. 295; Leathers v. Deloach, 140 Tenn. 259 (declaring mutuality to be jurisdictional); and case cited in note I. See also article by Harlan F. Stone in I6 CoI. I. REv. 443, reviewing late decisions of the New York courts.

14 Montgomery Traction Co. v. Montgomery Power Co., 229 Fed. 672 (certiorari denied, 242 U. S. 628) ; Great Iakes, etc., Co. v. Scranton Coal Co., 239 Fed. 603; Union Bag Corp'n v. Bischoff, 255 Fed. I87 (holding federal courts not bound by state decisions); Reo Motor Car Co. v. Young, 


\section{The Newer Conception of Mutuality-Mutual, Performance of Mutiual, Obligations.}

The negative doctrine of equality or identity of remedy is going. The principle of mutuality remains. Both Ames and Lewis differentiated this principle from the false doctrine of equality, but they differed as to the precise nature of the principle and neither carried its analysis far enough. ${ }^{15}$ It is the purpose of this paper,

209 Mich. 578; Gregory Co. v. Shapiro, I25 Minn. 8I; First Nat'l Bank v. Corporation Securities Co., I28 Minn. 34I; Schuyler v. Kirk-Brown Realty Co., 178 N. Y. Supp. 568; Great Northern Ry. Co. v. Cheyenne Telephone Co., 27 N. D. 256; Naylor v. Parker (Tex. Civ. App.), I39 S. W. 93; Wright v. Suydam, 72 Wash. 587; and see note 5 .

J. N. Pomeroy, Jr., in the first edition of his EQUIrABLE REMIEDIES attempted a restatement of Fry's doctrine, but it amounted to nothing more than the inclusion within the "general rule" of some of the exceptions, for it still embodied the doctrine of equality of remedy. EQ. Rass. (Ed. rg05), \$769 ff. In his last edition he has wholly repudiated this doctrine and accepted the views of Dean Ames, a fortunate circumstance in view of the vogue of the Pomeroy treatise.

It should be added that the earlier writers recognized the true principle of mutuality as well as the principle of equality, but did not carry the analysis of either far enough to see their exact value or the interrelation of the two. Cf. with passages referred to in note I, FRY, SpEcific PERformance, \$543, ff.; Pomeroy, SpectFic Performance, \$\$40, 330; Watiriman, Specific Perrorarance, \$39o, ff. Likewise, some of the older cases discussed and applied the principle of mutuality without in any way becoming involved with the principle of equality. See, for example, Buck v. Smith, 29 Mich. 166, where Graves, C. J., said: "Among the primary considerations is the question whether the substantial sense and design of both parties can be worked out by the decree of the court, since the real equity of the proceeding, the spirit of the particular jurisdiction means performance on both sides and not a compulsory surrender by one party to another without a present substantial and practical equivalent, an equivalent susceptible of enforcement and execution by the court." But it was not enough that an occasional case rang true. Most of the cases being argued on the theory of equality, it was necessary to meet that theory squarely and reduce it to subjection.

15 To this cavalier comment it should be added that the work of Ames and Lewis was of primary importance. As Josh Billings remarked, "It's not so much people's ignorance that makes trouble as their knowing so much that ain't so." Ames and Lewis cleared the darkened counsels of two centuries and set us on the road to sound doctrine. This work was one of the utmost difficulty, requiring at once patient industry and broad vision, and its accomplishment entitles these writers to the highest rank among practical 
building upon the work of those scholars, to elaborate the truth which they revealed.

The principle of mutuality, as now understood, has to do with the mutual performance of mutual obligations and is concerned entirely with securing performance by plaintiff as well as by defendant. Hence it is involved only when a court is asked to enforce a bilateral contract which has not been fully performed on plaintiff's side. It says nothing about equality of remedy. It has nothing to do with any hypothetical case that might have arisen if the now plaintiff had broken the contract and the now defendant had sued. It is concerned entirely with the situation now before the court. What it says about that situation may be roughly stated thus: the contract must be considered as a whole, and the obligations of the plaintiff looked to as well as those of the defendant; so far as practicable, both parties should be required to perform their obligations at the same time; and if simultaneous performance is impracticable the court should either enforce the contract upon terms which will give defendant some assurance of future performance by plaintiff, or refuse to enforce the contract at all-whichever is the more just, considering the situation of both parties.

In terms of equitable maxims, the principle is not that equality is equity, but that he who seeks equity must do equity, and that equity delights to do justice, and not by halves. The doctrine of mutuality is, then, own brother to the doctrines of hardship and of completeness, all deriving from the same fundamental concepts of equity.

One finds, of course, under the two heads "hardship" and "mutuality" quite different manifestations of the principle, but the fundamental principle is the same. It may be said to be this: that a court of equity is not bound to enforce a legal obligation, even though the remedy at law is inadequate, but may, when justice to the defendant requires it, refuse relief altogether or grant relief only on terms. As the principle is not susceptible of formulation

jurists. Their attention being fixed upon the exposure of the fallacy in the doctrine of equality, it is not surprising that they rested when they had achieved this end. And though they left much to be done, they accomplished the most important and the most difficult part of the task. 
in definite rules, it has very much the character of justice without law. ${ }^{16}$ The principle is, however, firmly established. ${ }^{17}$

The relation of mutuality and completeness is obvious, for mutuality commonly leads the court either to compel complete performance on both sides or refuse relief altogether. The two are not, however, inseparable, for the court may be satisfied that mutuality is sufficiently secured, though the case is not completely disposed of.

We are discussing mutuality in specific performance, strictly a matter of procedure in equity. We should not, however, think of mutuality as a doctrine of equity which has no counterpart in the common law. In truth, much the same principles have been worked out at law, though expressed in very different terms. ${ }^{18}$ The basic principle which both law and equity should observe is thus happily expressed by Mr. Williston:

"In a bilateral contract not only are the promises consideration for one another, but the parties contemplate that the performances also shall be exchanged one for the other; in other words, in a bilateral contract a double exchange is contemplated, first of promises and later of performances."19

The common law has endeavored to work out this principle in terms of implied conditions, a characteristic fiction, and in terms of the measure of damages. The results are not altogether satisfactory, but in the main observe the equities of the situation as far as the limitations of common law procedure permit. For the present purpose it will suffice to state these results as follows. ${ }^{20}$ While the law formerly treated mutual promises, unless expressly conditioned one tupon the other, as independent, each to be enforced regardless of the performance or non-performance of the other, it now inclines to treat mutual promises as interdependent, so that both sides of the contract must be looked to. Of course, common law cannot

10 See Dean Pound's article, "Justice According to Law," I3 CoL. I. REv. 696; I4 ib. I, r03. Also, "Decadence of Equity," 5 CoL. L. REv. 20.

17 Even in actions at law the courts have not infrequently refused to enforce the letter of the law because of hardship-e. $g$., cases cited in SEDGWICK, DaMages (Ed. 9), \$606c.

1827 HaRv. I. REV. 2I7; WIILISTOON, CONTRACTS, §I440.

10 Contracts, §8I3.

20 For a masterly discussion of the common law doctrines, see WILLISTon, Confracrs, Chapter 26 , and $\$ 1349, f$. 
directly enforce a contract except by damages, and damages, as such, can only be given in case of breach, and breach cannot occu1 on both sides, save as to breach of merely subsidiary promises, total breach on both sides being impossible. ${ }^{21}$ Neither can the common law give a conditional judgment, that defendant pay damages if the plaintiff performs. But it can, and in many cases does, say that defendant's promise is not absolute, to perform at all events, but is conditional or qualified, so that non-performance by plaintiff, or repudiation, or even prospective inability to perform, may excuse defendant from performance and constitute a complete defense to plaintiff's action. Thus, in the familiar case of a contract to sell goods, the law, in the absence of a stipulation for credit, makes payment of the price a condition concurrent to the seller's obligation to deliver, and the buyer suing for non-delivery must allege and prove readiness and willingness to pay and a tender, unless tender has been waived. Even though credit is stipulated for, insolvency, producing a prospective inability to pay, excuses the seller from his obligation. And even where defendant cannot make out a defense, the default being his rather than plaintiff's, or plaintiff's default being too trivial to constitute an equitable defense, yet if plaintiff's promise has not been fully performed the damages will usually be reduced by deduction of the value of the performance promised by plaintiff from the value of the performance promised by defendant. Thus, our hypothetical purchaser, if he recovers at all, will get judgment for the value of the goods less the agreed price. This, in effect, is enforcing in damages the promises of both parties, plaintiff collecting the excess of his damages, if any.

Thus, the common law usually secures mutuality of performance of a bilateral contract, though under other names and by very different machinery from that employed by equity. The chief differences between the equitable doctrine of mutuality and the related doctrines of the common law arise from the difference in the form of the relief, from the greater flexibility of equitable remedies, and notably from the fact that many contracts which the law stands ready to enforce as best it can, equity cannot or will not enforce at all-e.g., the contract for personal services.

21 Repudiation on both sides, or breach on one side and repudiation on the other side, are possible, but this amounts substantially to rescission, and would not give each party a right of action for damages. 


\section{AfFiRMative AND NEGATIVE Aspects of MUtuality}

The doctrine of mutuality of performance, like the exploded doctrine of equality or identity of remedy, has both an affirmative and a negative aspect. In its affirmative aspect, mutuality requires that, if defendant is compelled to specifically perform his promises, the court should see that he obtains, or has reasonable assurance of obtaining, the agreed equivalent, performance of plaintiff's promises. In its negative aspect the doctrine of mutuality demands that, if defendant cannot be reasonably assured of performance on plaintiff's side, he should not be compelled to perform at all.

It is obvious that there is a vast difference between the two aspects of the doctrine. The affirmative doctrine is altogether beneficent, while the negative doctrine is devastating and its application can only be justified where this is the lesser of two evils. It is, of course, assumed that the contract sought to be enforced is not only valid but fair and reasonable, one that should be effectively enforced. Such being the case, the affirmative doctrine of mutuality is altogether acceptable because it tends to the complete enforcement of the contract. The only possible question upon this head is one of ways and means. What may properly be done to secure the defendant that reciprocity of performance to which he is obviously entitled? On the other hand, the negative doctrine of mutuality is always harsh, since it leads to the denial of equitable relief, and this in a case where, ex hypothesi, the plaintiff has no adequate remedy at law ${ }^{22}$ leads, then, to a substantial denial of justice. In this it is like the negative doctrine of equality of remedy. There is, however, this vital difference between the two doctrines, that the equity of equality is too attenuated to justify this denial of justice, whereas the equity of mutuality may in some cases be so strong that denial of relief constitutes the lesser of two evils.

The last point has not passed without challenge. Mr. Lewis attacked it with great vigor and contended that the record of cases in which defendant had succeeded in this defense was a record of "gross miscarriages of justice." ${ }^{23}$ An effort will be made in this

22 If plaintiff does not make at least a prima facie case of inadequacy of the remedy at law there is no occasion to consider the defense of want of mutuality.

${ }^{23} 42$ Asr. L. REGG. (n. s.) 625, ff. 
paper to meet his arguments, but for the moment it must suffice to join issue upon this sweeping condemnation of the doctrine. It must be admitted that the doctrine is harsh, but in some cases its application is justified. Mr. Lewis was, however, more than half right, for too many of the cases where the defense has succeeded do involve miscarriage of justice. The doctrine of mutuality as exemplified in the decisions partakes too much of the character of sanctuary for contract breakers.

The sources of error are chiefly these. First, there has been, until recently the failure even to approximate a sound analysis of the problem, most of the cases being reasoned on the old dogma of equality of remedy. Then there has been, even on the part of those who have seen the vice in the equality dogma, an unfortunate tendency to formulate a rigid and mechanical doctrine of mutuality which, in the name of justice to the delinquent defendant, too often inflicts gross injustice upon the innocent plaintiff. Lastly, the negative aspect of the doctrine has been over-emphasized and the development of its affirmative aspect neglected, with the result that courts, overlooking the available means of protecting defendant while compelling him to perform, have frequently dismissed bills which should have been granted on terms. Of the three sources of error mentioned, the first, the equality fallacy, is becoming mere matter of history, thanks to Ames and Lewis. The other two, the mechanical treatment of mutuality and the failure to realize upon its affirmative and beneficent aspect, still flourish.

\section{ThE AfFirmative DoctrINE-RELIEF on TERMS}

Let us restate the problem of mutuality. Complainant has made a prima facie case by establishing a valid contract, breach or threatened breach by defendant, and inadequacy of the remedy at law, but he has not fully performed the contract on his side. This does not necessarily mean that plaintiff is guilty of breach or non-performance of conditions. The doctrine of mutuality comes into play whenever the contract contains promises on plaintiff's side which have not been performed prior to the hearing, even though performance by defendant is due first and he is in default. In every such case, it is plain equity that there should be mutual performance of the mutual promises. 
Defendant may assert this equity in two ways. He may admit plaintiff's title to relief and merely assert his own equity to performance by plaintiff; or he may set up want of mutuality as an absolute defense. These positions are very different, yet it matters not at the outset which of them defendant takes. Though he asserts want of mutuality as a defense, the court must first consider whether it is not possible to work out a decree which will secure mutuality, yet compel defendant to perform. If this were not done, want of mutuality would be established in every case of a bilateral contract executory on both sides. Always, then, the question of mutuality is first of all a question upon the affirmative aspect of the doctrine. And this, as was said before, is merely a question of ways and means. What devices has the court at its command with which to secure the equities of the defendant, and how should it use them? The devices are the conditional decree and performance with a variation, or, as it has been happily called, $c y$ pres performance. ${ }^{24}$

The term "conditional decree" is here used in the sense of any decree which is qualified with reference to performance by plaintiff. Under strict practice, no order can be made against plaintiff in the absence of a cross-bill, ${ }^{25}$ but for the purpose of securing mutuality the conditional decree is even more effective than an affirmative order. The decree may be conditional in form, containing a proviso that qualifies its whole command, as in the familiar decree that a vendor execute and deliver a deed upon plaintiff tendering the price, or, in the case of continuing obligations, a decree requiring defendant to perform so long as plaintiff performs the obligations resting upon him. Again, the decree may interpose conditional action by a master, as in the decree requiring the vendor to deliver a deed to a master, to be delivered by him to the purchaser upon the latter paying the price into the hands of the master. Or the decree, while laying upon defendant an unconditional command to perform a continuing obligation, may reserve leave to apply for dissolution of the decree upon plaintiff's failure to perform his

\footnotetext{
24 The application of the phrase cy pres, so familiar in connection with charitable trusts, to specific performance with a variation is not common, but it is certainly convenient and illuminating. It was so used by Lord Langdale in Thomas v. Dering, $x$ Keen 729, 746, and by Beasley, C. J., in King v. Ruckman, 24 N. J. Eq. 556.

${ }^{25} 2$ I C. J. 667.
} 
obligations. ${ }^{26}$ The choice between these several forms of decree should be determined by considerations of expediency upon the circumstances of each case. ${ }^{27}$ It matters little for the purpose of this paper which of them is used.

$C_{y}$ pres performance, or performance with a variation, is not a device alternative to the other, but one which may be combined with it. The principle is merely that the court is not put to the dilemma of enforcing the contract precisely according to its terms or refusing to enforce it at all, but may enforce it with a variation, cy pres (as near as may be) to the terms of the contract. ${ }^{2 s}$ One example will suffice for the present. In Van Scoten v. Albright, ${ }^{29}$ a contract for the sale of land called for conveyance on April I, following, and provided for the payment of $\$ 200$ on the day set for conveyance and the balance of the price in annual instalments which would run through more than eight years. The contract did not provide for a mortgage to secure the deferred payments. On April I, the pur-

${ }^{26}$ Such a decree may appropriately be termed interlocutory (2I C. J. 642 ), though it is not necessarily interlocutory in the sense, whatever that may be, in which interlocutory decrees are said to be unappealable (3 C. J. 432).

${ }_{27}$ It has been said that a conditional decree is void (2I C. J. 645), but this can be true only of some extraordinary sort of condition, if at all. It has also been said that the question whether conditions have been performed should be settled under the eye of the court (2I C. J. 668). Of course, in one sense this question must ultimately be settled by the court, upon an attachment for contempt, if not sooner. But in any case where there is likelihood of dispute as to whether plaintiff has performed, it would seem to be good practice to settle this matter at an earlier stage-e. $g$., in the case of continuing obligations, to reserve leave to move-for dissolution instead of issuing an injunction with a self-executing condition. And there can be no objection to this practice in every case-e. g., requiring the purchaser plaintiff to pay the purchase money into court instead of requiring its payment directly to defendant.

28 In the well-known hardship case of Willard, v. Taylor, 8 Wall. 557, Justice Field said: "It is the advantage of a court of equity, as observed by Lord Redesdale in Davis v. Hone, that it can modify the demands of parties according to justice, and where, as in that case, it would be inequitable, from a change of circumstances, to enforce a contract specifically, it may refuse its decree unless the party will consent to a conscientious modification of the contract, or, what would generally amount to the same thing, take a decree upon condition of doing or relinquishing certain things to the other party."

295 N. J. Eq. 467. 
chaser tendered the $\$ 200$ and his notes for the balance, but the vendor refused to convey and demanded a mortgage. Purchaser sued. By the terms of the contract, conveyance was due, but payment, save of the first instalment, was not. If the court should enforce the contract according to its terms, it would compel performance by defendant without requiring performance or security for performance on plaintiff's side. It is true that such a decree would not violate the rule of mutuality which was formulated by Dean Ames: "Equity will not compel specific performance by a defendant if, after performance, the common law remedy of damages would be his sole security for the performance of the plaintiff's side of the contract."30 Defendant would not be left to the common law remedy of damages, for he could sue, in equity to collect the price. ${ }^{31}$ But, as a means of collecting from an irresponsible debtor, the suit in equity would be no better than an action at law. ${ }^{32}$ If the court could only enforce the contract according to its terms, the defense of want of mutuality would be difficult to meet. ${ }^{33}$ But the court easily avoided the difficulty by decreeing conveyance upon the execution of a mortgage for the deferred instalments of the purchase price. Plaintiff could make no substantial objection to this variation of the contract, for he had no equity to enjoy the land without paying for it.

${ }^{30} 3$ CoL. L. REV. I, 12. In the midst of his paper Ames expressed his conception of mutuality in these terms: "The reciprocity of remedy required is not the right of each party to maintain a bill for specific performance against the other, but simply the right of one party to refuse to perform, unless performance by the other is given or assured." 3 CoL. L. REv. 8. It is submitted that this is a better statement of the principle than the other, but Ames clearly preferred the other, with which he began and concluded his paper.

31 The bill would be based on the affirmative doctrine of equality of remedy. A vendor succeeded on this ground in Hopper v. Hopper, I6 N. J. Eq. 147, and that court would presumably entertain a bill by a vendor, although he had conveyed and was therefore able to recover the price, as distinguished from difference money, in an action at law.

32 Statutes and constitutions abolishing imprisonment for debt make it impossible to enforce a money decree founded on a mere contract obligation, save by execution or similar process against the property of the defendant. I3 C. J. I2.

${ }^{33}$ Semble, that on a substantially similar case relief would have to be denied, the court overlooking the possibility of security, Bentley v. Barnes, IJI Ala. 5I2. 
This sort of thing, which has the appearance of making a new contract for the parties, has met censure. ${ }^{34}$ In its most extreme manifestation, when a court at the suit of the vendor compels a purchaser to take, at a price fixed by the court, property which is less in some respect than he agreed to buy and the vendor agreed to sell, the doctrine is certainly open to question. Even when the court forces a vendor, who has not all that he agreed to sell, to convey what he has with compensation, though the variation is forced upon the party in default at the election of the other, the doctrine is one that may work hardship and should be applied cautiously. But when the variation is unquestionably favorable to defendant and is not forced upon plaintiff, but is merely made a qualification upon the relief which is offered him, in such cases the objection to cy pres performance is merely academic. Especially is this true when cy pres relief presents itself as the only practicable alternative to the dismissal of the bill. The negative doctrine of mutuality works constant hardships which may be largely eliminated by a liberal use of the cy pres principle.

In this connection it may be well to recall the point made by Professor Langdell, that specific performance (in a strict sense) of affirmative contracts is seldom attained. What is usually secured is the doing of what was agreed to be done, but not at the time when it was agreed to be done. ${ }^{35}$ As an argument for replacing the familiar term "specific performance" by "specific reparation for breach of contract," this may be meticulous, but the fact remains that in wholly normal cases what the court really does is to frame a decree which will secure action as near (cy pres) to performance of the contract as the circumstances will permit. Occasionally the mere lapse of time introduces real difficulty. The point is nicely

${ }^{34} \mathrm{Mr}$. Lewis said: "For the purpose of overcoming the objections to the specific enforcement of a contract as made the court cannot insert provisions which do not form part of the agreement." 42 Ass. L. REG. (n. s.) 6II, note. Dean Ames ignored this solution of the problems.

35 I HARV. L. REv. 355; "Brief Survey of Equity Jurisdiction," 40. Langdell's statement is even stronger than that attributed to him in the text. He says that "equity does not attempt to enforce performance of affirmative duties $* * *$ in fact, a bill will not lie (any more than an action at law will lie) upon an affirmative contract until the contract is broken." See, however, Noyes v. Bragg, 220 Mass. 106. 
illustrated by King v. Ruckman. ${ }^{36}$ The contract, made on May I2, $x 868$, called for conveyance on July $I$, at which time $\$ 80,000$ was to be paid in cash and the residue of the price secured by bond and mortgage "payable in five equal annual payments from the date of said agreement." Vendor refused to convey, and purchaser sued. After protracted litigation, it was determined that the contract ought to be enforced, and a dispute then arose as to the terms of the decree, defendant contending that as the time for payment of the deferred instalments (one, two, three, four, and five years from the date of the contract) had already passed, the decree ought to be conditioned upon payment in cash: that to give the purchaser further time would work "an alteration of the contract." The vicechancellor, however, decreed conveyance upon the execution of a mortgage which would give to the purchaser the same time for payment, after he acquired title, which he would have had if the contract had been closed in accordance with the terms of the contract. 'This decree was affirmed by the Court of Errors. ${ }^{37}$ Beasley, C. J., said :

"The contract, on this point, cannot now be carried into effect. The stipulated time for the giving of the title on the one side, and the mortgage on the other, has gone by and is irretrievable. From the necessity of the case, there must be something substituted in this respect for what the parties agreed. It is impracticable to execute the contract in this particular except upon the doctrine of cy pres. The decree, in this feature of it, goes upon the theory that the stipulation for time for the payment of the residuum of the price, after the acquisition of the title of the purchaser, was a subtantial part of the agreement, and it seems to me that this is well founded in the merits of the case. After a vendee gets

${ }^{36} 24$ N. J. Eq. 556.

${ }^{37}$ In Lombard v. Chicago Sinai Congregation, 75 Ill. $27 \mathrm{r}$, on similar facts, the court decreed payment in cash. Surely, the letter of the contract killeth here. And the reason assigned for this holding, "The contract could only be enforced as the parties themselves had made it," is utterly inconsistent with the principal point in the decision, viz., that the vendor must convey the land for the agreed price less compensation for buildings which had been destroyed after the execution of the contract. The court did not let its left hand know" what its right hand was doing. 
title and the possession he is then in a position to turn the land to account in the way of raising money." 38

We may say, then, that the common decree for specific performance is merely an order requiring action which will be as near (cy pres) to performance of the contract as is practicable under the circumstances; that a decree which imposes upon plaintiff conditions which were not provided for in the contract differs only in degree, not in kind, from the common variety; that there can be no impropriety in imposing such conditions for the purpose of securing mutuality; and that the problem is merely to devise a decree which will observe the true substance and spirit and equity of the contract as distinguished from its letter.

The cases are numerous which have turned plaintiff out of court without considering the possibility of cy pres relief. These cases are not, however, authority against the granting of $c y$ pres relief, for the reason that such relief was not asked for. ${ }^{38^{a}}$ On the other

${ }^{38} C y$ pres relief necessitated by lapse of time is also to be seen in the very numerous cases in which an equitable adjustment has been made between vendor and purchaser with respect to interest and profits. Enforcing the contract long after the time stipulated for completion, there is a clear obligation on the party in default (on the part of the purchaser to pay interest on the purchase money wrongfully withheld, on the part of the vendor to account for the rents and profits of the land wrongfully withheld), but there is no such obligation on the party not in default. Yet the courts, feeling that in justice one party should not have both the use of the land and the use of the money, have made reciprocity the dominant principle. In one such case, Sanborn, J., said: "The purpose of the specific performance of a contract is to place the parties as near as may be in the same situation that they would have occupied if they had voluntarily performed it. The compulsory performance of it and the terms of the decree therefore rest in the sound judicial discretion of the chancellor, which should be exercised to - attain this object. All the rules which have been established for the moulding of decrees have been framed and followed and all the exceptions to them have come into being to accomplish this purpose and are subordinate to its attainment." Beckwith v. Clark, I88 Fed. I7r.

$38^{\mathrm{a}}$ The point is more than that upon which the authority of decisions is so often shaken, viz., that a principle applicable to the decision was not discussed. The point is that the court was called upon to grant one kind of relief, and its refusal of that does not involve the refusal of another kind of relief. It might be argued that these cases indicate the opinion of court and counsel that such relief was impossible, and such may indeed have been their opinion. But this is no more than conjecture. For all that appears, 
hand, we have a number of well considered cases in which the court exercised its prerogative of variation in order to secure mutuality. There are enough of these decisions to give us a firm foundation in authority for the application of the cy pres principle, and an intelligent application of that principle will go far toward the elimination of the hard features of the doctrine of mutuality.

\section{The Negative Doctrine-ReifeF Denied For WANT OF MUTUALITY}

But it will not always be possible to secure performance to both parties. Cases arise in which no decree can be framed which will give plaintiff substantial relief and at the same time secure to defendant performance of plaintiff's promise. In this situation, defendant insists that the bill should be dismissed, and this presents the negative aspect of the doctrine of mutuality.

Mr. Lewis contended that this defense should never be admitted. It will be worth while to quote his argument at length:

"Take a typical case. A may contract with $B$ that $B$ shall convey to him land, and in consideration thereof A will, after conveyance, serve $B$ for one year. In this case, should the court make $B$ perform his side of the contract, it is possible that A may resell the land and then refuse to perform

plaintiff may have refused cy pres relief, preferring a dismissal without prejudice.

It is not here asserted that a special prayer is necessary to found cy pres relief. It would seem that the prayer for specific performance would support a decree for performance on terms, since this amounts. to granting the prayer in part. And it is certain that a prayer for general relief would found such a decree, although there is some conflict as whether it will support a decree requiring defendant to perform in part with compensation. 20 Enc. P1. \& Pr. 5II, ff.

Neither is it asserted that a plaintiff who sought specific performance and was met with the defense of want of mutuality would be entitled, as of right, to a dismissal without prejudice, as against proffered cy pres relief. It would seem that, if the terms imposed are not at all onerous, the court should apply the principle that, after hearing, a plaintiff is not entitled to a voluntary dismissal, but must submit to the decision of the court. On the other hand, if the terms proposed are so onerous as to approximate a denial of relief, the court should apply the principle that a dismissal based on a rule of equity procedure should be without prejudice. Between these extremes, it would seem that discretion must govern. 
his side of the contract. In such an event the court would not only be unable to give $B$ specific performance, which in the writer's eyes is no reason for now refusing $A$ specific performance, but would be unable to restore the land to $B^{39}$ and $B$ can unquestionably claim that he has a right, as between himself and $A$, to such restoration on A's failure to perform the promised services. Yet we may presume that in the case put the contract was a fair one. *** If the court forces the defendant to live up to his contract in either case they enforce a fair contract, and they never place the defendant in any position which, under his fair contract, he would not have placed himself had he been an honest man. Why should the court, being able to make the delinquent defendant live up to his obligations, hesitate to do so because they would place him in a position in which he has expressly agreed to place himself?" 40

Elsewhere he adds the argument that plaintiff, having performed or offered to perform up to the time of decree, will probably perform after the decree. ${ }^{41}$

The argument is forcible and exposes an inherent weakness in the defense. But the matter is put too strongly. Looking only to the construction of the contract, the defendant may, indeed, have agreed to perform on his side without receiving prior or contemporaneous performance on plaintiff's side, and may to this extent have agreed to trust to the credit of the plaintiff and such remedies as law and equity would give him. But strict enforcement of contract is not always just. The parties seldom, if ever, have contemplated all the contingencies that may arise in case of dispute, directing their attention almost exclusively to the effect of full and willing performance. When the transaction miscarries and disputes arise the court should not confine its attention to the terms of the bargain, but should consider the whole of the situation that is pre-

39 The case is one in which it is possible to give cy pres relief which will fairly protect defendant, and this has sometimes been granted, but, for the purpose of the argument, we may assume with $\mathrm{Mr}$. Lewis that it cannot be given or that the court is unwilling to give it.

${ }_{40}^{42}$ AM. I. REG. (n. s.) 628 .

$41 \mathrm{Ib} .626$. 
sented. Even though the defendant has wantonly broken his contract (and probably most breaches are, from the ethical point of view, not without their circumstances of mitigation), the defendant is not an outlaw who has forfeited all claim to justice. And though the plaintiff will probably perform without any pressure being brought to bear upon him, it is by no means certain that he will. In the case $\mathrm{Mr}$. Lewis puts, plaintiff's conduct really demonstrates nothing save that he desires the land and is willing, if necessary, to render the services as a means to that end. If the court gives him the land without requiring performance of the services or putting some sort of pressure upon him to perform, he may lose all interest in his undertaking. Again, in the case of a contract calling for continuing action on both sides, over a long term, though conditions now render mutual performance beneficial to plaintiff so that he desires to perform, but onerous to the defendant so that he desires to avoid performance; yet in course of time conditions may be reversed. In either case, there is an element of hardship in compelling defendant to perform the onerous part of the contract without reasonable assurance that he will have performance by plaintiff. It should be remembered that a decree in equity compelling defendant to perform in full without performance or assurance of performance by plaintiff is much more harsh than the usual judgment at law upon a bilateral contract which, charging defendant only with difference money, in effect enforces both sides of the contract at once. It is submitted that there is necessarily a substantial element of hardship in non-mutual enforcement of a bilateral contract, and that it may in some cases be sufficient to justify the denial of specific performance. Nothing is clearer than that the courts have thought so.

It is a serious mistake, however, to formulate the doctrine of mutuality in any such mechanical rule as that which was propounded by Dean Ames:

"Equity will not compel specific performance by a defendant if, after performance, the common law remedy of damages would be his sole security for the performance of the plaintiff's side of the contract. ${ }^{92}$

42 It is certain that Dean Ames would never have urged the application of this rule to the defeat of justice. Quite properly, he strove for a definite 
On the one hand, as we have already seen, this rule will not in all cases give the defendant proper protection. On the other hand, there are cases where it is more just to compel defendant to perform, even though he may be left to the common law remedy of damages, than it would be to deny plaintiff all relief.

In the much-cited case of Standard Fashion Co. v. Siegel-Cooper Co., ${ }^{43}$ the contract provided for the sale of plaintiff's patterns in defendant's department store for a term of two years. Plaintiff through its own employees was to conduct the pattern department, and defendant was to provide certain space for the purpose and certain general service, such as wrapping, cashiering and delivery. Defendant also stipulated that it would not sell or allow to be sold on its premises, during the life of the contract, any other make of patterns. The proceeds of the sales were to be divided on a percentage basis. Before performance was begun defendant repudiated and contracted for the sale of other patterns. To the bill for specific performance defendant demurred. The demurrer was overruled, the court saying that even if specific performance of the whole contract were refused as impracticable,

"the bill should be retained as one permitting an adjudication, in the sound judicial discretion of the court, to restrain the defendants from violating the negative and severable covenant of the Siegel-Cooper Company that it would not

rule, but the whole spirit of his paper on mutuality, and of his other writings as well, was that rules and formulae must yield to the requirements of practical justice. He aimed at the destruction of the old formula of equality of remedy, and succeeded well. Incidentally, he propounded a formula to supplant the old one, and its superiority cannot be seriously questioned. Unfortunately, this formula, thotgh superior in every other respect, is quite as rigid as the old one. And, unfortunately, we appear to be fairly in the way to make the new formula as sacrosanct as the old one was. It has been several times approved by the courts (see note 14), and Mr. Pomeroy adopted it, with a slight variation in phraseology, in his article on "Specific Performance" in 36 Cyc. 622, and incorporated it verbatim in the last edition of the popular and almost authoritative EQUTTABLE REMIEDIES, $\$ 769$.

43 I57 N. Y. 60. Followed on substantially similar facts in Butterick Publishing Co. v. Fisher, 203 Mass. I22; Peerless Pattern Co. v. Gauntlett Dry Goods Co., I7I Mich. I58; Butterick Publishing Co. v. Rose, I4r Wis. 533. Cases more or less analogous are legion, but those in which defendant was entitled to a definite money compensation are hardly on the same footing with respect to the possible hardship on defendant. 
sell $* * *$ any other make of paper patterns. $* * *$ the court should extend its remedy as far as it is able and thus prevent the principal defendant not only from making money by breaking its agreement but from inflicting a double wrong upon the plaintiff by depriving it of the right to sell and conferring that right on a business competitor. $* * *$ The injunction, when granted, may not be absolute, but may be based on some equitable condition that will prevent either party from taking advantage of the other."

How does this case measure up to Ames' rule? It is safe to say that the court would not undertake affirmative enforcement of plaintiff's promises any more than it would defendant's. Nor could it give negative relief against plaintiff corresponding to that which it gives against defendant, ${ }^{44}$ for the contract did not provide that plaintiff would not sell through other sources and defendant has no equity to an "exclusive agency" in the absence of an understanding to that effect. ${ }^{45}$ Defendant has, then, no security for plaintiff's performance, save as conditions attached to the decree may provide it. The decree would, of course, make provision for the release of defendant from the injunction if, it being ready to perform the whole contract, plaintiff should refuse to perform. This will give defendant a sort of day-to-day security for reciprocal performance. But defendant's right is larger than this. The contract is entire and defendant, performing on its side, is entitled to full performance by plaintiff. Suppose that, under the pressure of the injunction, defendant cancels its contract with the third party and permits the sale of plaintiff's patterns as agreed; and suppose that, before the expiration of the contract, plaintiff, finding the contract onerous and being able to make more advantageous arrangements, refuses to carry on; and suppose that defendant is then

44 It has sometimes been suggested that in the cases where negative relief is given upon a contract which is both affirmative and negative, mutuality might be secured by giving similar negative relief against plaintiff. CrARK, EQUITY, §I8O.

45 Contract to that effect would not be necessary. In Butterick Publishing Co. v. Fisher, 203 Mass. I22, where plaintiff had, dehors the contract, expressed the intention of giving defendant an exclusive privilege, the court refused relief until plaintiff terminated its relations with other dealers. $C_{y}$ pres performance again. 
unable to make an equally advantageous contract elsewhere. Such things have been commonplace in recent years. In our supposititious case, defendant would have no security against plaintiff's breach save an action at law for damages. The court might condition its decree upon plaintiff's giving bond for the payment of such damages, ${ }^{46}$ and this would take care of the credit risk, but it is clear that defendant's damages would be so far conjectural as to make the remedy impracticable, ${ }^{47}$ and no decree can be framed which will eliminate that difficulty from the case. ${ }^{48}$ Such being the situation before the court, it is obvious that there was a certain element of hardship in compelling defendant to perform his promise. Perfect mutuality was not attained. And Ames' formula was not satisfied, unless upon a very broad interpretation. ${ }^{49}$ Yet, in spite of the really serious objection to specific performance in this case, it is clear that the court reached a just decision. It subjected defendant to the risk of hardship, but if it had denied relief it would have subjected

${ }^{46}$ See McCaull v. Braham, I6 Fed. 37.

47 Theoretically, the damages would be the net profit which might have been realized through performance of the contract, less the net profit which might have been secured through arrangements with some other party. It is obvious that these items could not be proved with accuracy, and it is doubtful whether any proof could be made which would satisfy the rule of law as to speculative damages. Witherbee v. Meyer, I55 N. Y. 446; Ramsey v. Holmes Electric Co., 85 Wis. 174 .

$48 \mathrm{It}$ would undoubtedly be within the power of the court to condition relief upon the execution by plaintiff of a bond for the payment of liquidated damages in a sum estimated by the court as reasonable. But this would be no more than a guess at an adequate remedy, and it is quite unlikely that any court would care to undertake the speculation.

49 "If damages would be his sole security" is literally susceptible of interpretation as requiring merely some security for some part of plaintiff's obligations, but Ames assuredly did not intend such a proposition. In the light of the whole of his paper, it would seem that Dean Ames' conception of mutuality might be expressed in these terms: "The reciprocity of remedy required is not the right of each party to the contract to maintain a bill for specific performance against the other, but simply the right of one party to refuse to perform unless performance by the other is given or reasonably assured." 'This is Ames' own language, save for the word "reasonably." See 3 Cor. I. Riv. 8. But the formula upon which he deliberately took his stand, and which has been made so much of, runs otherwise. The inconsistency of this rule with Lumley v. Wagner was pointed out by Prof. Barry Gilbert in an article in $4 \mathrm{CAL}$. I. REV. II5, 127. The inconsistency with the principal case is greater in that defendant's remedy at law is less practicable. 
plaintiff to a certainty of hardship at least equal in degree, for the measure of plaintiff's damages in an action at law would have been so far conjectural as to make that remedy a farce of justice. ${ }^{50}$ On the side of defendant there is possibility, hardly probability, of hardship. On the side of plaintiff there is certainty of hardship. And the danger to which defendant is subjected in performing the contract is a danger inherent in the position which he agreed to take, and hence may be said to be a danger which he agreed to assume; while the hardship to which plaintiff is subjected by a breach of the agreement is one which he did not agree to bear, but, contrariwise, was insured against by the contract. These are arguments which Lewis urged in support of a total abolition of the defense of want of mutuality. They are used here in a very different way, in support of the treatment of the defense as an equitable defense turning on the balance of conflicting equities.

An interesting contrast to the last case is to be seen in that familiar class of cases where defendant has agreed to convey land in consideration of services to be rendered by plaintiff, which have not been fully performed at the time of hearing. In many of these cases it is possible to work out cy pres relief which will fairly secure defendant, and even though defendant should be left without other security than an action at law, that remedy would, in the case of ordinary services, be more practicable than that to which the SiegelCooper Company might have been put. Yet when we weigh the plaintiff's equity to relief we find that it is not comparable to that of the Fashion Company. A vendee of land obtains equitable relief as a matter of course, and this undoubtedly has, in practically all cases, a substantial foundation in the fact that the value of land is

50 In Butterick Publishing Co. v. Fisher, 203 Mass. I22, the court said of plaintiff's claim for damages: "We think that doubtless it has suffered damages, but we think also that it is not possible to prove, and that the plaintiff has not proved, what they amount to in dollars and cents." In the principal case the court suggested as one of the equitable conditions which might be embodied in the decree a "waiver by the plaintiff of the breach of the contract." The prosecution of a claim for damages would be merely vexatious.

If the only aim in the administration of justice were to attain perfect mutuality, that could easily be secured in cases of this type by sending both parties to law, where neither would be compelled to perform without receiving counter-performance-no, nor on any other terms. 
more or less conjectural. The purchaser makes a prima facie case of inadequacy of the remedy at law, quite sufficient to warrant relief if no equity of defendant is opposed, yet his action at law is not unmanageable. A purchaser who is to pay for the land in services would find his remedy at law somewhat more involved than would the money purchaser, for the item to be subtracted from the value of the land, in mitigation of damages, would not be a liquidated price but the sum which the purchaser realized, or should have realized, by the employment of his time in other occupations. Even so, this purchaser's remedy at law is not wholly unserviceable, and is by no means a farce of justice. One may disapprove of many of the decisions which have denied relief upon this type of case, but it cannot be doubted that they are distinguishable from the pattern cases, distinguishable on the basis of balance of equities. The defense in the land case is weaker because cy pres relief is possible and because the simple action at law furnishes defendant a more practicable remedy; but, on the other hard, plaintiff's equity to specific relief is weaker because his remedy at law is more practicable.

Looking broadly now at the whole problem, is it not obvious that in dealing with the defense of want of mutuality, a defense the substance of which is hardship on the defendant, a sound solution must involve a balance of equities? Unless we are ready, in the name of justice to a delinquent defendant, to inflict gross injustice on an innocent plaintiff, we must either abolish the defense altogether or put it on this basis. Ames made a valiant effort to formulate the principle of mutuality in a rule that would be at once certain and just, but he obviously failed. ${ }^{51}$ Nor can any other mechanical rule or set of rules be framed which will observe the equities of the situation. And the reason is not far to seek. The equities involved, the elements of practical justice on either side of the case, are not absolute but relative. Too often it is assumed, as the very term "want of mutuality" suggests, that mutuality is an absolute quantity which is or is not. In truth, perfect mutuality probably does not exist this side of Paradise, and on the other hand, one who performs merely on the faith of the other's legal obligation and the remedy at law does not give something for nothing. What we have

51 Failed on one head or the other. See note 49. 
to consider is not mutuality and lack of mutuality, but mutuality more perfect and mutuality less perfect. Likewise, on plaintiff's side, the hardship of a denial of equitable relief (in other words, the inadequacy of the remedy at law) is not an absolute but a relative quantity, existing in all degrees from the case where the action at law would be a mere farce of justice to the case where it merely fails to be "as efficient to the ends of justice" as the remedy in equity. In such a situation, mechanical rules will necessarily be as cruel as Procrustes' bed. Practical justice can be attained only by the exercise of a broad discretion.

This will leave us with a rule that is vague and uncertain, and certainty is a valuable quality in law. But when certainty demands the elimination of flexibility and discretion from equitable remedies, the price it asks is too great. ${ }^{52}$ There are signs that the profession is coming to realize that in the nineteenth century passion for certainty we paid too much for that commodity, and that perhaps we did not obtain the certainty we bargained for, but rather an illusion of certainty. ${ }^{.3}$ The pendulum seems to be swinging back toward discretion, flexibility, and individualization of justice, especially in the remedial field. We will be in the right line of legal development if, in dealing with mutuality, we abandon the ideal of cer-tainty and leave the courts free to administer justice upon the circumstances of each case, guided only by broad principles of equity. That this is the right disposition of the problem of mutuality has not commonly been admitted.54 Discussion of the subject has usually carried the implication (seldom more) that the doctrine of

62 "Certainty, it is true, would thus be attained, but it would be the certainty of injustice." Thus spoke Justice Christiancy upon a question very different from ours, but like it in being a problem in remedial justice. Allison v. Chandler, II Mich. 542, 555.

53 The promulgation of a neat formula creates the appearance of certainty. But the application of the rule may be shrouded in uncertainty. And if the rule is inherently unsound and productive of injustice, the courts will more or less consistently evade the rule or riddle it with arbitrary exceptions, and this gives us not only uncertainty but also a misleading statement of the law. The gulf which may exist between the formula in the books and the law in action is strikingly illustrated in every aspect of the subject of mutuality.

54 But see Montgomery Traction Co. v. Montgomery Power Co., 229 Fed. 672, where the Circuit Court of Appeals scrutinized in a practical and 
mutuality is inflexible. The actual decisions of the courts have, however, observed the balance of equities to an extent that is remarkable in view of the almost total absence of explicit recognition of that principle. In other words, most of our courts could adopt the discretionary view without overruling any of their decisions or repudiating any of their explicit utterances. And since the whole subject of mutuality is in the crucible and many courts have indicated a desire to recast it in the mold of practical justice, it is not too much to hope that the discretionary view will prevail. EDGAR NOBLE DURFEE.

\section{University of Michigan Law School.}

(To be continued)

realistic manner the position in which the decree of the District Court placed defendant, and concluded that "the circumstances of the instant case fairly negative the conclusion that the decree appealed from involved the inequitable result, the avoidance of which is the prime object of the rule as to mutuality of remedies. *** We are not of opinion that $* * *$ the court exceeded the broad powers permissible to be used in affording relief of that nature, the use or non-use of which powers is left to the sound judicial discretion of the court, to be exercised with reference to the particular facts of the case dealt with." (Certiorari denied, 242 U. S. 628.)

In Zelleken v. Lynch, 8o Kan. 746, where Burch, J., said: "The plaintiff's claims appeal to conscience and are unopposed by any countervailing equity on the defendant's side. *** It may be assumed that the plaintiffs will obey the law and keep their promise. Manifestly, it is just and equitable and will thwart a fraud now to decree specific performance in plaintiff's favor, and manifestly, it would be unjust and inequitable and would allow the perpetration of a fraud not to do so. That is sufficient. If scientific or other considerations demand a formula governing the subject, whoever needs can phrase one on that basis." 